\title{
A Urological Twist: Literature Review, An Australian Experience and Management Algorithm for Knotted Ureteric Stents
}

\author{
(D) Brendon W.H. Lee $1,2,3$, (D) Anthony-Joe Nassour1,2, (D) Darius R. Ashrafi1,2,4, (D) Andrew J. Mitterdorfer ${ }^{1}$ \\ ${ }^{1}$ Bankstown-Lidcombe Hospital, Clinic of Urology, Sydney, Australia \\ 2University of New South Wales Faculty of Medicine, Sydney, Australia \\ 3 University of Sydney Medical School, Sydney, Australia \\ 4 University of Queensland School of Medicine, Brisbane, Australia
}

\begin{abstract}
Knotted ureteric stents remain a rare complication, with only 34 cases reported to date. They require prompt recognition and skilful management to avoid ureteric injury. Knots more often occur at the proximal end of stents, have a male preponderance, are associated with multi-length stents and relate to the J-coil configuration, which is affected by the renal pelvis anatomy, hydroureter and presence of urolithiasis. We present our experience of a knotted stent managed using holmium:yttrium aluminium garnet laser and traction. We also provide an updated literature review and recommend a treatment algorithm for this rare but important complication.
\end{abstract}

Keywords: Knotted ureteric stent, holmium:YAG laser, stent removal, multi-length stent, percutaneous nephrostomy, treatment algorithm

\section{Introduction}

Ureteric stents are an indispensable component of modern urological practice. Knot formation is a rare complication but must be recognised to prevent ureteric injury. To date, 34 cases (26 papers) of knotted ureteric stents have been reported since its first description in 1989 (Supplementary Table 1)(1). Herein, we report an illustrative case where holmium:yttrium aluminium garnet Ho:YAG laser was utilised to remove stent encrustation and enabled stent removal using gentle traction. The optimal management for the retrieval of a knotted ureteric stent is contextual, but we provide a recommended treatment algorithm using a graded approach.

\section{Case Presentation}

A 31-year-old man presented with sudden-onset left flank pain, rigours, anorexia and vomiting. He had left nephrolithiasis that was managed conservatively, but he had no past medical history. He was haemodynamically stable and had an unremarkable abdominal examination with no evidence of peritonism or renal angle tenderness. Microscopic haematuria was noted on urinalysis. The provisional diagnosis was renal colic, and a computed tomography kidney, ureter and bladder scan demonstrated a left $8 \times 6 \times 6 \mathrm{~mm}^{3}$ proximal ureteric calculus with mild hydroureteronephrosis. Emergency ureteric stenting was undertaken due to intractable pain despite use of non-steroidal anti-inflammatory and opioid analgesia. An intraoperative retrograde pyelogram (RGP) demonstrated a thin distal left ureter with a proximal filing defect corresponding with the location of the ureteric calculus. Moderate difficulty was encountered traversing the obstruction during stent insertion. A 5-Fr multi-length Double-J stent was eventually deployed successfully. Completion intraoperative X-ray imaging demonstrated satisfactory stent placement.

During the definitive stone procedure, performed 6 weeks later, there was significant difficulty in retrieving the ureteric stent. Intraoperative fluoroscopy revealed a knot at the proximal J-coil of the ureteric stent (Figure 1). Gentle traction under fluoroscopic guidance was used to tease the knotted stent into the distal ureter; however, further traction was met with resistance, and the knot could not be moved beyond the vesicoureteric junction. Ureteroscopy demonstrated significant debris and heavy encrustation around a tight knot, resulting in a widened diameter that impeded stent extraction (Figure

Correspondence: Brendon W.H. Lee MD, Bankstown-Lidcombe Hospital, Clinic of Urology, Sydney, Australia

E-mail: Brendon-lee@live.com.au ORCID-ID: orcid.org/0000-0001-7678-1067

Received: 19.11.2020

Accepted: 25.12 .2020

Cite this article as: Lee BHW, Nassour AJ, Ashrafi DR, Mitterdorfer AJ. A Urological Twist: Literature Review, An Australian Experience and Management

Algorithm for Knotted Ureteric Stents. J Urol Surg 2021;8(2):151-155.

๑Copyright 2021 by the Association of Urological Surgery / Journal of Urological Surgery published by Galenos Publishing House. 


\begin{tabular}{|c|c|c|}
\hline $\begin{array}{l}\text { Removal } \\
\text { technique }\end{array}$ & Indication & $\begin{array}{l}\text { Anaesthetic } \\
\text { required }\end{array}$ \\
\hline Traction & $\begin{array}{l}\text { 1. First-line } \\
\text { 2. Should be completed } \\
\text { with real-time fluoroscopic } \\
\text { guidance }\end{array}$ & $\begin{array}{l}\text { Local or general/ } \\
\text { spinal }\end{array}$ \\
\hline Guidewire & $\begin{array}{l}\text { 1. When traction } \\
\text { encounters significant } \\
\text { resistance or if further knot } \\
\text { tightening visualised }\end{array}$ & General/spinal \\
\hline $\begin{array}{l}\text { Endoscopic } \\
\text { guided }\end{array}$ & $\begin{array}{l}\text { 1. If traction and/or } \\
\text { guidewire unsuccessful } \\
\text { 2. To provide visualisation } \\
\text { of the knot }\end{array}$ & General/spinal \\
\hline $\begin{array}{l}\text { Holmium YAG } \\
\text { laser }\end{array}$ & $\begin{array}{l}\text { 1. Significant stent } \\
\text { encrustation } \\
2 . \text { Knot diameter prevents } \\
\text { removal } \\
\text { 3. To fragment the knot or } \\
\text { severe the stent below the } \\
\text { knot }\end{array}$ & General/spinal \\
\hline $\begin{array}{l}\text { Percutaneous } \\
\text { removal }\end{array}$ & $\begin{array}{l}\text { 1. Unable to advance } \\
\text { ureteroscope to level of } \\
\text { knot } \\
\text { 2. Patient unable to } \\
\text { undergo general or spinal } \\
\text { 3.Fragments in renal pelvis } \\
\text { unable to be removed } \\
\text { endoscopically }\end{array}$ & $\begin{array}{l}\text { Local or general/ } \\
\text { spinal }\end{array}$ \\
\hline $\begin{array}{l}\text { Open } \\
\text { ureterotomy or } \\
\text { surgery }\end{array}$ & $\begin{array}{l}\text { 1. Failure of all less invasive } \\
\text { options } \\
\text { 2. Ureteric avulsion }\end{array}$ & General \\
\hline
\end{tabular}

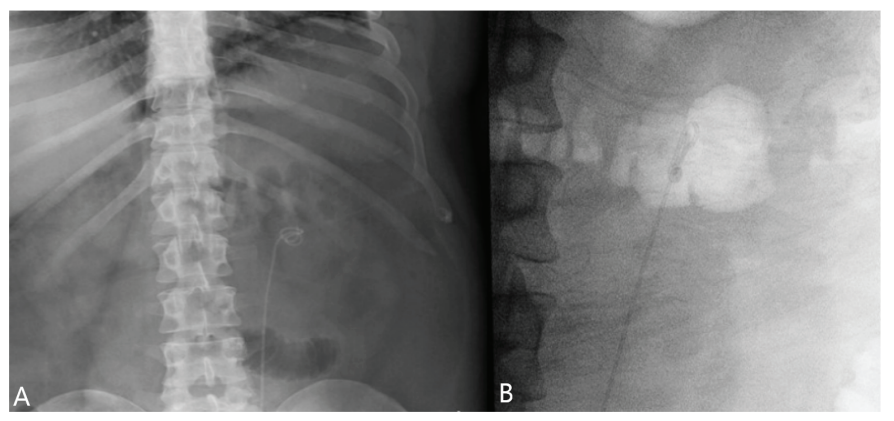

Figure 1. At the second-stage procedure, 6 weeks after initial left ureteric stent insertion, a preoperative X-ray kidney, ureter and bladder taken 24 hours earlier demonstrated an abnormal configuration in the proximal J-coil that may have formed during stent insertion and/or predisposed to knot formation during stent retrieval (A). Intraoperative fluoroscopy demonstrated knot formation at the proximal J-coil of the ureteric stent after significant difficulty was met during traction retrieval (B)

2). Careful laser lithotripsy of the encrustation/debris reduced the diameter, increased the mobility of the distal knot and facilitated stent extraction with gentle traction. No contrast extravasation was identified on completion RGP to suggest

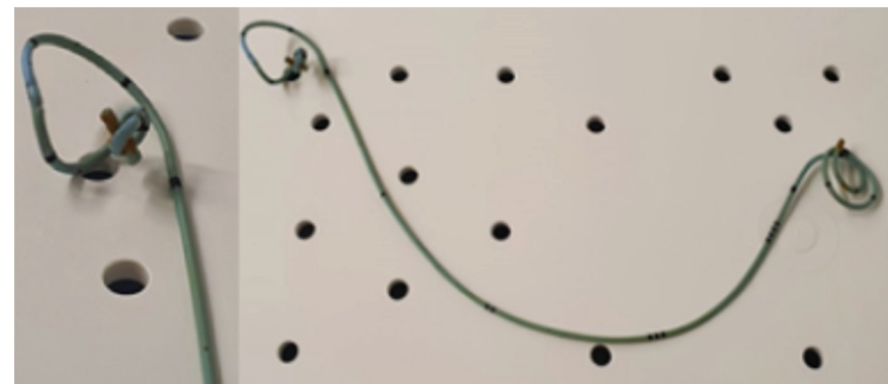

Figure 2. Left ureteric stent demonstrating knot formation in the proximal J-coil with residual encrustation following lithotripsy and extraction. Significantly more encrustations were observed during ureteroscopy around the knot, which increased its diameter and prevented extraction and passage at the vesicoureteric junction

ureteric injury. No residual collecting system calculi were identified on completion ureteropyeloscopy. The patient had an uncomplicated postoperative course, with no issues at the 6-month follow-up period. The patient provided informed written consent for the publication of the case.

\section{Discussion}

The mechanism of knot formation remains unclear. However, studies have demonstrated higher occurrence at the proximal end (only three cases reported at the middle or distal end), male preponderance $(4: 1)$ and association with excessive stent length and coil formation $(2,3)$.

Multi-length stents are preferred because they are easier to use, reduce stent migration risk and cost-effective (4). However, they appear to knot more often with 18 of the 24 previous cases, that reported stent length, being multi-length stents. Studies have proposed that the increased length leads to excessive proximal coiling, which occurs after the stent abuts the wall of the renal pelvis $(4,5)$. Subsequently, a knot forms when the stent passes through this open coil $(6,7)$. Fixed-length stents may decrease knot occurrence, but have their own issues (4). By contrast, stent diameter does not appear to affect knot formation, as diameters ranging from 4.7 to $7 \mathrm{Fr}$ have been observed (3).

Yamamoto et al. (8) suggested that knotting occurs during insertion, possibly due to excessive guidewire coiling within the renal pelvis, rather than during retrieval. Patient factors like the renal pelvis anatomy and presence of hydronephrosis or urolithiasis may further alter the configuration of the proximal J-coil during insertion, thereby predisposing to knot formation (3). Interestingly, an analysis of previous cases demonstrated that knot formation occurred more often in cases without hydronephrosis than with hydronephrosis (9).

Stent encrustation on knotted stents can add difficulty during stent retrieval, as it increases the knot diameter and prevents passage of a guidewire through the stent lumen (10). We 
postulate that encrustation increases the friction during retrieval, which impedes the uncoiling process and possibly precipitates knot formation. However, knots have occurred in stents without significant encrustation $(10,11)$.

No clinical practice guidelines exist for the management of knotted stents. We present a recommended treatment algorithm for knotted ureteric stents based on the literature and our experience, summarised in Table 1. For instance, we recommend simple traction with real-time fluoroscopic guidance, which is successful in most cases. Traction can lead to tightening of the knot or ureteric avulsion, although no studies have reported avulsion (5).

If significant resistance is met during traction or the knot is tightened, attempts at straightening the knot should be pursued using a guidewire. This has been successfully completed using an Amplatz super stiff guidewire and straight tip guidewire $(7,11)$.

If this is unsuccessful, possibly due to confounding stent encrustation that occludes the stent lumen, endoscopic extraction should be pursued, as it allows for visualisation of the knot and facilitates more precise traction, knot manipulation and/or application of the holmium:YAG laser $(3,6,12,13)$. This requires general or spinal anaesthesia and adequate advancement of the ureteroscope to the level of the knot, which can be restricted by urethral strictures, obstructing urolithiasis or the stent itself in a narrow calibre ureter (10).

Holmium:YAG laser was first utilised to remove a knotted stent in 2011 (12). The laser can be used to fragment/sever the stent below the knot, fracture the knot itself or remove stent encrustation/debris $(4,10,12,13)$. This technique is minimally invasive and reproducible and allows for direct visualisation, which reduces the occurrence of inadvertent ureteric damage
$(3,12)$. Excessive fragmentation of the ureteric stent should be avoided, as this requires removal using basket, graspers or percutaneous nephrostomy if endoscopic techniques fail $(10,13)$.

Percutaneous nephrostomy is useful in patients who cannot undergo a general or spinal anaesthesia or if endoscopic removal is unsuccessful $(2,3,9,10,14,15)$. The first case was performed in Australia after failure of traction and endoscopic retrieval (15). Other techniques have utilised a Terumo guidewire in a patient with steinstrasse, Amplatz guidewire through a dilated nephrostomy tract, and the use of a 26-Fr nephroscope via a superior caliceal puncture into the renal pelvis and upper ureter $(2,3)$. Open removal procedures can be considered, if all other methods fail.

\section{Ethics}

Informed Consent: The patient provided informed written consent for the publication of the case.

Peer-review: Externally peer-reviewed.

\section{Authorship Contributions}

Surgical and Medical Practices: B.W.H.L A.J.N., D.R.A., A.J.M., Concept: A.J.N., D.R.A., A.J.M., Design: B.W.H.L, D.R.A., A.J.M., Data Collection or Processing: B.W.H.L, A.J.N., D.R.A., A.J.M., Analysis or Interpretation: B.W.H.L, A.J.N., D.R.A., A.J.M., Literature Search: B.W.H.L, A.J.N., D.R.A., Writing: B.W.H.L, A.J.N., D.R.A., A.J.M.

Conflict of Interest: No conflict of interest was declared by the authors.

Financial Disclosure: The authors declared that this study received no financial support. 


\begin{tabular}{|c|c|c|c|c|c|c|c|}
\hline \multicolumn{8}{|c|}{ Supplementary Table 1. Updated review of knotted ureteric stent literature } \\
\hline Author & Year & Patient & Stent model & Stent length & Indication for stent & $\begin{array}{l}\text { Knot } \\
\text { location }\end{array}$ & Removal method \\
\hline Groeneveld & 1989 & N/A & N/A & N/A & N/A & Proximal & Traction distally during cystoscopy \\
\hline $\begin{array}{l}\text { Das and } \\
\text { Wickham }\end{array}$ & 1990 & $45 \mathrm{M}$ & Single J & $\mathrm{N} / \mathrm{A}$ & Nephrolithiasis & Distal & Traction distally during cystoscopy \\
\hline $\begin{array}{l}\text { Braslis and } \\
\text { Joyce }\end{array}$ & 1992 & $37 \mathrm{~F}$ & 4.7 Fr double J & Multilength & Nephrolithiasis & Proximal & Percutaneous \\
\hline Kundargi & 1994 & $53 \mathrm{M}$ & 6 Fr double J & $26 \mathrm{~cm}$ & Nephrolithiasis & Proximal & Percutaneous \\
\hline Flam et al. & 1995 & $86 \mathrm{M}$ & 6 Fr double J & $26 \mathrm{~cm}$ & Ureterolithiasis & Proximal & $\begin{array}{l}\text { Alligator forceps to untie knot } \\
\text { in situ and traction during } \\
\text { ureteroscopy }\end{array}$ \\
\hline Baldwin et al. & 1998 & $73 \mathrm{M}$ & 7 Fr double J & Multilength & $\begin{array}{l}\text { Transitional cell } \\
\text { carcinoma }\end{array}$ & Proximal & $\begin{array}{l}\text { Amplatz super stiff guidewire } \\
\text { inserted through stent to untie knot } \\
\text { in situ }\end{array}$ \\
\hline Quek and Dunn & 2002 & $66 \mathrm{~F}$ & 7 Fr double J & $24 \mathrm{~cm}$ & Nephrolithiasis & Mid & Traction distally during cystoscopy \\
\hline Sighinolfi et al. & 2005 & $48 \mathrm{M}$ & 5 Fr double J & Multilength & Nephrolithiasis & Proximal & $\begin{array}{l}\text { Extracorporeal shock wave } \\
\text { lithotripsy followed by continuous } \\
\text { traction with the stent attached to } \\
\text { patient's leg for } 3 \text { days }\end{array}$ \\
\hline $\begin{array}{l}\text { Corbett and } \\
\text { Dickson }\end{array}$ & 2005 & $4 \mathrm{M}$ & 4.7 Fr double J & Multilength & $\begin{array}{l}\text { Reimplantation } \\
\text { of an obstructed } \\
\text { megaureter }\end{array}$ & Proximal & Traction distally during cystoscopy \\
\hline Kondo et al. & 2005 & $37 \mathrm{M}$ & 6 Fr double J & Multilength & Nephrolithiasis & Proximal & Open ureterotomy \\
\hline Eisner et al. & 2006 & $82 \mathrm{~F}$ & $\begin{array}{l}6 \text { Fr Cook Kwart } \\
\text { Retro-Inject } \\
\text { stent }\end{array}$ & Multilength & Nephrolithiasis & Proximal & $\begin{array}{l}2 x \text { extracorporeal shock wave } \\
\text { lithotripsy and laser lithotripsy } \\
\text { during ureteroscopy }\end{array}$ \\
\hline Eisner et al. & 2006 & $82 \mathrm{~F}$ & $\begin{array}{l}6 \text { Fr Cook Kwart } \\
\text { Retro-Inject } \\
\text { stent }\end{array}$ & Multilength & $\begin{array}{l}\text { Excessive } \\
\text { manipulation during } \\
\text { stent removal }\end{array}$ & Proximal & $\begin{array}{l}\text { Traction after forceful coughs that } \\
\text { induced valsalva and caused knot to } \\
\text { come undone }\end{array}$ \\
\hline Basavaraj et al. & 2007 & $70 \mathrm{~F}$ & 6 Fr double J & Multilength & $\begin{array}{l}\text { Nephrolithiasis and } \\
\text { ureterolithiasis }\end{array}$ & Proximal & Rigid conduitoscopy \\
\hline Rivalta et al. & 2009 & $83 \mathrm{M}$ & $7 \mathrm{Fr}$ & $\mathrm{N} / \mathrm{A}$ & $\begin{array}{l}\text { Bladder and prostate } \\
\text { cancer }\end{array}$ & Proximal & $\begin{array}{l}\text { Traction with sterile petroleum jelly } \\
\text { within a ureterocutaneostomy }\end{array}$ \\
\hline $\begin{array}{l}\text { Picozzi and } \\
\text { Carmignani }\end{array}$ & 2010 & $41 \mathrm{~F}$ & $7 \mathrm{Fr}$ double J & $26 \mathrm{~cm}$ & $\begin{array}{l}\text { Ureteral injury } \\
\text { following surgery }\end{array}$ & Proximal & Traction distally during cystoscopy \\
\hline Richards et al. & 2011 & $67 \mathrm{M}$ & $\mathrm{N} / \mathrm{A}$ & $\mathrm{N} / \mathrm{A}$ & Ureterolithiasis & Proximal & $\begin{array}{l}\text { Holmium YAG laser during } \\
\text { ureterorenoscopy }\end{array}$ \\
\hline Tempest et al. & 2011 & $68 \mathrm{M}$ & 6 Fr stent & Multilength & Nephrolithiasis & Proximal & $\begin{array}{l}\text { Holmium YAG laser and removal } \\
\text { using tri-radiate graspers }\end{array}$ \\
\hline Moufid et al. & 2012 & $32 \mathrm{M}$ & Double J & $\mathrm{N} / \mathrm{A}$ & Ureterolithiasis & Proximal & $\begin{array}{l}\text { Traction proximally during } \\
\text { ureteroscopy with fluoroscopic } \\
\text { guidance }\end{array}$ \\
\hline Karaguzel et al. & 2012 & $53 \mathrm{M}$ & 4.7 Fr double J & $28 \mathrm{~cm}$ & Ureterolithiasis & Proximal & $\begin{array}{l}\text { Foreign body forceps during } \\
\text { ureterorenoscopy }\end{array}$ \\
\hline Nettle et al. & 2012 & $43 \mathrm{M}$ & 6 Fr double J & $\mathrm{N} / \mathrm{A}$ & $\mathrm{N} / \mathrm{A}$ & Proximal & $\begin{array}{l}\text { Holmium YAG laser during } \\
\text { ureteroscopy }\end{array}$ \\
\hline Bhirud et al. & 2012 & $41 \mathrm{M}$ & Double J & $\mathrm{N} / \mathrm{A}$ & Nephrolithiasis & Mid & $\begin{array}{l}\text { Percutaneous using } 26 \mathrm{Fr} \\
\text { nephroscope }\end{array}$ \\
\hline Manohar et al. & 2014 & $65 \mathrm{M}$ & 4.8 Fr stent & Multilength & Ureterolithiasis & Proximal & Percutaneous, antegrade \\
\hline Manohar et al. & 2014 & $68 \mathrm{~F}$ & 4.8 Fr stent & Multilength & $\begin{array}{l}\text { Ureteric injury } \\
\text { following surgery }\end{array}$ & Proximal & Holmium YAG laser \\
\hline Manohar et al. & 2014 & $55 \mathrm{~F}$ & 6 Fr double J & Multilength & Nephrolithiasis & Proximal & $\begin{array}{l}\text { Holmium YAG laser during rigid } \\
\text { ureteroscopy }\end{array}$ \\
\hline
\end{tabular}




\begin{tabular}{|c|c|c|c|c|c|c|c|}
\hline Manohar et al. & 2014 & $59 \mathrm{M}$ & 4.8 Fr stent & Multilength & Nephrolithiasis & Proximal & Traction of stent on wire \\
\hline Ahmadi et al. & 2015 & $45 \mathrm{M}$ & $\begin{array}{l}6 \text { Fr double J } \\
\text { soft }\end{array}$ & Multilength & Nephrolithiasis & Proximal & $\begin{array}{l}\text { Holmium YAG laser and basket } \\
\text { to retrieve fragments under } \\
\text { ureteroscopy }\end{array}$ \\
\hline Ahmadi et al. & 2015 & $43 \mathrm{M}$ & $\begin{array}{l}6 \text { Fr double J } \\
\text { stiff }\end{array}$ & Multilength & Ureterolithiasis & Proximal & $\begin{array}{l}\text { Holmium YAG laser and basket to } \\
\text { retrieve fragments }\end{array}$ \\
\hline Ahmadi et al. & 2015 & $71 \mathrm{M}$ & $\begin{array}{l}7 \text { Fr double J } \\
\text { stiff }\end{array}$ & Multilength & $\begin{array}{l}\text { Retroperitoneal } \\
\text { fibrosis secondary to } \\
\text { treated lymphoma }\end{array}$ & Proximal & $\begin{array}{l}\text { Percutaneous after unsuccessful } \\
\text { holmium YAG laser }\end{array}$ \\
\hline Ahmadi et al. & 2015 & $71 \mathrm{M}$ & $\begin{array}{l}7 \text { Fr double J } \\
\text { stiff }\end{array}$ & Multilength & $\begin{array}{l}\text { Retroperitoneal } \\
\text { fibrosis secondary to } \\
\text { treated lymphoma }\end{array}$ & Proximal & Percutaneous \\
\hline Ahmadi et al. & 2015 & $52 \mathrm{M}$ & $\begin{array}{l}6 \text { Fr double J } \\
\text { soft }\end{array}$ & Multilength & Ureterolithiasis & Proximal & $\begin{array}{l}\text { Holmium YAG laser to remove } \\
\text { encrustation during rigid and } \\
\text { flexible pyeloscopy with retrieval } \\
\text { over a wire }\end{array}$ \\
\hline Kim et al. & 2015 & $53 \mathrm{M}$ & Double J & N/A & $\begin{array}{l}\text { Nephrolithiasis and } \\
\text { Ureterolithiasis }\end{array}$ & Proximal & Percutaneous, antegrade \\
\hline Zhou et al. & 2018 & $33 \mathrm{M}$ & 6 Fr double J & $26 \mathrm{~cm}$ & $\begin{array}{l}\text { Postoperative } \\
\text { ureterovesical } \\
\text { anastomotic stricture }\end{array}$ & Proximal & $\begin{array}{l}\text { Holmium YAG laser and basket to } \\
\text { retrieve fragments }\end{array}$ \\
\hline Bradshaw et al. & 2019 & $57 \mathrm{~F}$ & N/A & N/A & $\begin{array}{l}\text { Bilateral } \\
\text { vesicoureteric } \\
\text { junction radiation- } \\
\text { induced strictures }\end{array}$ & Proximal & $\begin{array}{l}\text { Percutaneous, antegrade removal } \\
\text { using Amplatz guidewire and } \\
\text { dilation of nephrostomy tract using } \\
\text { serial metal dilators }\end{array}$ \\
\hline Cho & 2020 & $62 \mathrm{M}$ & 6 Fr double J & Multilength & Ureterolithiasis & Proximal & $\begin{array}{l}\text { Straight tip guidewire to untie knot } \\
\text { under fluoroscopic guidance }\end{array}$ \\
\hline
\end{tabular}

\section{References}

1. Groeneveld AE. The role of ESWL in the treatment of large kidney stones. Singapore Med J 1989;30:249-254.

2. Bhirud $P$, Giridhar $V$, Hegde P. Midureteric knotted stent removed by percutaneous access! Urol Ann 2012;4:106-107.

3. Bradshaw J, Khan A, Adiotomre E, Burbidge S, Biyani CS. Antegrade removal of a knotted ureteric stent: Case report and review of literature. Urol Ann 2020;12:96-100.

4. Manohar P, Kan WT, Ranasinghe WK, Cetti RJ, McCahy P. Knotted multilength ureteric stents: a case series. ANZ J Surg 2016;86:413-414.

5. Picozzi S, Carmignani L. A knotted ureteral stent: A case report and review of the literature. Urol Ann 2010;2:80-82.

6. Flam TA, Thiounn N, Gerbaud PF, Zerbib M, Debré B. Knotting of a double pigtail stent within the ureter: an initial report. J Urol 1995;154:1858-1859.

7. Baldwin DD, Juriansz GJ, Stewart S, Hadley R. Knotted ureteral stent: a minimally invasive technique for removal. J Urol 1998;159:2065-2066.

8. Yamamoto $M$, Kanaoka $Y$, Hara $Y$. Difficulty in removing a multilength ureteral stent due to knotting: a case report. Nishinihon J Urol 2004;66:657660.
9. Kim MS, Lee HN, Hwang H. Knotted stents: Case report and outcome analysis. Korean J Urol 2015;56:405-408.

10. Ahmadi N, Tran M, Elms M, Ko R. Knotted proximal loop of ureteric stents: Review of the literature and five case reports. J Clin Urol 2014;8:432-437.

11. Cho CL. A knotted ureteral stent. Urol Case Rep 2020;33:101327.

12. Richards MM, Khalil D, Mahdy A. Successful treatment of stent knot in the proximal ureter using ureteroscopy and holmium laser. Case Rep Med 2011;2011:502191.

13. Tempest H, Turney B, Kumar S. Novel application of an established technique for removing a knotted ureteric stent. BMJ Case Rep 2011;2011:bcr1120103528.

14. Kondo N, Yoshino Y, Shiono Y, Hasegawa Y. [A case demonstrating knot formation at the upper end of a ureteral stent]. Hinyokika Kiyo 2005;51:385387.

15. Braslis KG, Joyce G. Spontaneous knotting of a pigtail ureteric stent in the ureter requiring percutaneous removal. Aust N Z J Surg 1992;62:825-826. 